\title{
Pannus Formation
}

National Cancer Institute

\section{Source}

National Cancer Institute. Pannus Formation. NCI Thesaurus. Code C50686.

Superficial vascularization of the cornea with infiltration of granulation tissue; an

inflammatory exudate overlying the lining layer of synovial cells on the inside of a joint. 